\title{
Nano drug delivery systems for ovarian cancer therapy
}

\author{
Canan Hascicek* and Ozge Gun \\ Ankara University, Faculty of Pharmacy, Department of Pharmaceutical Technology, Turkey
}

\begin{abstract}
Ovarian cancer is the second most common gynecologic cancer in Europe and the USA, and the most fatal gynecologic malignancy among all cancers with a mortality rate of $6 \%$. The traditional treatment of ovarian cancer includes cytoreductive surgery and platinum-taxane combined chemotherapy. Although the response to the standard treatment scheme is promising at first, the disease often recurs and eventually treatment fails with the development of chemoresistance as the main cause of failure of treatment. The purpose of this brief review is to summarize the new strategies, especially in terms of nanotechnology, for the treatment of ovarian cancer.
\end{abstract}

\section{Introduction}

Ovarian cancer is the most lethal gynecologic cancer due to its high recurrence rate [1-3] even though it is one of the most sensitive tumors, even at advanced stage [4]. Today, it globally ranks fifth place among the causes of death for women [2,3]. The first-line treatment of ovarian-cancer is cytoreductive surgery followed by platinum-based chemotherapy [2-8]. Despite improvements in the field of medicine, the reason for high mortality in ovarian cancer is late diagnosis because of nonspecific symptoms [9] (almost 75\% [8,10] at stage III or later), and relapse of the disease ${ }^{1-3}$. The most significant reason for the recurrence of ovarian cancer is resistance to platinum-based chemotherapy in the majority of patients in progressive stages, although the initial success in treatment with agents such as cisplatin or carboplatin is more than $70 \%[3,11]$. It is known that resistant cancer cells develop resistance to platinum compounds by reducing cell uptake, increasing elimination, inactivation/detoxification of drugs, and accelerating DNA repair [1214]. Efforts are being made to develop new treatment options due to the frequency of platinum resistance $[3,15]$. For this purpose, various drug delivery and administration approaches have been developed such as the use of the intraperitoneal route, use of passive and/or active targeting nano drug delivery systems $[16,17]$.

Nanotechnology can be a solution for obstacles of ovarian cancer treatment. When recent studies were reviewed, along with developments in nanobiological fields, nanotechnology was found to have extensively investigated for molecular imaging, drug delivery, treatment and tumor targeting. Particulate drug nanocarriers such as liposomes, niosomes, polymeric micelles, solid lipid nanoparticles and polymeric nanoparticles have unique features for interacting with tumor microenvironments and tumor targeting as their submicron size, functional surfaces, stability, possibility to encapsulate hydrophobic drugs, prolong the residence time in systemic circulation $[18,19]$. Generally, conventional chemotherapy applications result in rapid blood clearance, degradation, undesirable side effects rooting from drug distribution to healthy tissues, poor drug accumulation in tumor tissues due to poor penetration capacity and multidrug resistance (MDR) [20].

Nanotechnology-based drug delivery systems can be beneficial for the controlled delivery of chemotherapeutics by means of location and duration without undesirable side effects by overcoming several drug delivery barriers through passive or active targeting strategies $[11,20]$.
The main goal of many nanostructuring applications is to protect the drug from rapid degradation after systemic application, to improve the pharmacokinetic behaviour of drugs by preventing rapid clearance of drugs by the reticulo-endothelial system (RES), to achieve therapeutic drug concentrations in the tumor site, to reduce side effects as much as possible by blocking drug delivery to normal tissues, to achieve more effective treatment by providing controlled release within the therapeutic window, to modulate the MDR mechanism by modifying drug uptake [20-22]. Additionally, a study indicated that nanocarriers can both enhance the sensitivity of tumor cells to chemotherapeutics and limit metastasis of the tumor [23]. Some examples of the passive and active targeted nano drug delivery systems can be seen in Table 1.

\section{Passive targeting}

Nano drug delivery systems for targeting tumors are based on the delivery of anti-tumor drugs within nanocarriers capable of targeting tumor tissues by taking advantage of the physiological and pathological characteristics of tumors [23]. The superiority of nanoparticulate systems in cancer treatment is mainly based on the enhanced permeability and retention (EPR) effect of the surrounding vessels of the tumor $[23,24]$. Increased accumulation of nanoparticles in tumor sites is due to the abnormal vasculature with a $200-800 \mathrm{~nm}$ pore size, whereas normal vessel endothelium has $5-10 \mathrm{~nm}$ pores. These wider pores result in the leakage of tumor vessels and reduced lymphatic drainage leading to an EPR effect and accumulation of nanoparticles in the tumor tissue $[21,23]$.

Cai et al. developed a linear-dendritic copolymer system (referred to as telodendrimer) via peptide chemistry for the co-delivery of paclitaxel, a low dose hydrophobic drug, and cisplatin, a hydrophilic drug. The single-drug loaded telodendrimers displayed less cytotoxicity than free drugs due to the slow release profile; however, telodendrimers loaded with two drugs showed significantly higher cytotoxicity against

Correspondence to: Canan Hascicek, Associate Professor, Ankara University Faculty of Pharmacy, Department of Pharmaceutical Technology, 06100 Tandogan, Ankara, Turkey, Tel: +90 (312) 2033157, Fax: +90 (312) 2131081, E-mail: cogan@pharmacy.ankara.edu.tr

key words: ovarian cancer, drug delivery system, nanotechnology, targeting

Received: April 04, 2017; Accepted: April 22, 2017; Published: April 25, 2017 
Table 1. Nano drug delivery systems for ovarian cancer therapy

\begin{tabular}{|c|c|c|c|c|c|c|c|}
\hline Drug & Delivery System & Targeting ligand & Carrier material & Preparation method & Characteristics & Results & Ref. \\
\hline $\begin{array}{l}\text { Parthenolide / } \\
\text { Doxorubicin }\end{array}$ & Micel & - & $\begin{array}{l}\text { PSMA-b-PS } \\
\text { PMSA-b-PBA }\end{array}$ & Self-Assembly & $\begin{array}{c}\text { Micel size: } 20-100 \mathrm{~nm} \\
\text { PDI: } 0,03-0,25 \\
\text { Zeta potential : } \\
-40 \mathrm{mV} /-50 \mathrm{mV} \\
\text { Encapsulation efficiency: } \\
>70 \% \text { for parthenolide }\end{array}$ & $\begin{array}{c}\text {-Improved internalization, } \\
\text { efficacy and higher } \\
\text { cytotoxicity }\end{array}$ & {$[20]$} \\
\hline $\begin{array}{c}\text { Paclitaxel / } \\
\text { Cyclopamine / } \\
\text { Gossypol }\end{array}$ & Micel & - & PEG-b-PCL & Solvent evaporation & $\begin{array}{l}\text { Micel size: } 80-90 \mathrm{~nm} \\
\text { Loading efficiency: } 9,4 \%\end{array}$ & $\begin{array}{l}\text {-Enhanced efficiency in } \\
3 \text {-D cell culture } \\
\text {-Dramatic reduction in } \\
\text { tumor volumes }\end{array}$ & [32] \\
\hline $\begin{array}{l}\text { Cisplatin / } \\
\text { Paclitaxel }\end{array}$ & Telo-dendrimer & - & $\begin{array}{c}\text { (III) } \mathrm{PEG}^{5 \mathrm{~K}} \\
(\mathrm{COOH})_{8}-\mathrm{L}-\mathrm{CA}_{8}\end{array}$ & Peptide chemistry & $\begin{array}{c}\text { Particle size: } 16.9 \mathrm{~nm} \\
\text { Loading efficiency: for } \\
\text { paclitaxel } 92 \%\end{array}$ & $\begin{array}{c}\text {-Higher cytotoxicity } \\
\text {-Higher accumulation at } \\
\text { the tumor site, antitumor } \\
\text { activity } \\
\text {-Improved } \\
\text { pharmacokinetic }\end{array}$ & {$[25]$} \\
\hline Genistein & Liposome & - & $\begin{array}{l}\text { HSPC, DOPE, } \\
\text { Cholesterol }\end{array}$ & Film hydration & $\begin{array}{c}\text { Particle size: } 159-407 \mathrm{~nm} \\
\text { Zeta potential : } \\
-19.4 /-22.6 \mathrm{mV} \\
\text { Encapsulation efficiency : } \\
73.5-93.1 \%\end{array}$ & $\begin{array}{c}\text {-Maximized membrane } \\
\text { incorporation, } \\
\text { pharmacological activity, } \\
\text { bioavailability and } \\
\text { pharmacokinetic }\end{array}$ & [33] \\
\hline $\begin{array}{l}\text { Irinotecan / } \\
\text { Doxorubicin }\end{array}$ & Liposome & - & $\begin{array}{c}\text { DSPC, } \\
\text { Cholesterol }\end{array}$ & $\begin{array}{l}\text { Thin film hydration, } \\
\text { followed by extrusion }\end{array}$ & $\begin{array}{l}\text { Encapsulation efficiency: } \\
\qquad>80 \%\end{array}$ & $\begin{array}{l}\text {-Improvement in } \\
\text { therapeutic efficacy due } \\
\text { to an increase in systemic } \\
\text { drug exposure, with } \\
\text { the maintenance of the } \\
\text { synergistic molar drug } \\
\text { ratio of } 1: 1 \text { in circulation }\end{array}$ & [34] \\
\hline Paclitaxel & $\begin{array}{l}\text { Nano-crystal } \\
\text { Hydrogel }\end{array}$ & - & Hyaluronic acid & $\begin{array}{l}\text { Temperature induced } \\
\text { crystallization }\end{array}$ & $\begin{array}{l}\text { Particle size: } 258 \mathrm{~nm} \\
\text { Zeta potential: }-5.51 \mathrm{mV}\end{array}$ & $\begin{array}{l}\text {-Greater cytotoxicity } \\
\text { and antitumor effect } \\
\text { microparticulate PTX gel } \\
\text { and free drug } \\
\text {-Extended survival of } \\
\text { tumor-bearing mice }\end{array}$ & {$[30]$} \\
\hline R547 & Micel & Transferrin & mPEG-PE & Lipid film hydration & $\begin{array}{c}\text { Micel size: } 13.2-15.5 \mathrm{~nm} \\
\text { Drug content: } \\
0.789-0.815 \%\end{array}$ & $\begin{array}{c}\text {-Improved interaction of } \\
\text { Tf-modified micelles with } \\
\text { A2780 ovarian carcinoma } \\
\text { cells } \\
\text {-Higher in vitro } \\
\text { cytotoxicity } \\
\text {-Decreased in vivo tumor } \\
\text { growth inhibition studies } \\
\text { in A2780-tumor bearing } \\
\text { mice }\end{array}$ & [19] \\
\hline Paclitaxel & $\begin{array}{l}\text { Nano- } \\
\text { particle }\end{array}$ & $\begin{array}{l}\text { Follicle-stimulating } \\
\text { hormone polypeptide }\end{array}$ & PEG-PLA & $\begin{array}{c}\text { Emulsion/solvent } \\
\text { evaporation technique }\end{array}$ & $\begin{array}{c}\text { Particle size: } 127.5 \mathrm{~nm} \\
\text { Zeta potential: }-35.3 \mathrm{mV} \\
\text { Entrapping efficiency: } 41.37 \%\end{array}$ & $\begin{array}{l}\text {-Improved cellular uptake } \\
\text {-Higher drug } \\
\text { concentrations in lymph } \\
\text { nodes } \\
\text {-Decreased tumor volume } \\
\text {-Increased survival time }\end{array}$ & [26] \\
\hline Shikonin & $\begin{array}{l}\text { Nano- } \\
\text { particle }\end{array}$ & $\begin{array}{l}\text { TEM1/ endosialin- } \\
\text { targeting antibody }(\mathrm{Ab})\end{array}$ & PLGA & $\begin{array}{c}\text { Single/double emulsion } \\
\text { solvent evaporation/ } \\
\text { diffusion technique with } \\
\text { sonication }\end{array}$ & $\begin{array}{c}\text { Particle size: } \\
120 \text { - } 250 \mathrm{~nm} \\
\text { Zeta potential: }-35 \mathrm{mV} \\
\text { Drug entrapment : } 42 \%\end{array}$ & $\begin{array}{l}\text {-Enhanced interaction with } \\
\text { TEM1-positive MS1 cells, } \\
\text {-Significant cytotoxicity }\end{array}$ & {$[35]$} \\
\hline siRNA & $\begin{array}{l}\text { Nano- } \\
\text { particle }\end{array}$ & Folic acid & $\begin{array}{l}\text { Poly (ethylene } \\
\text { glycol)-chitosan } \\
\text { oligo-saccharide } \\
\text { lactate (PEG- } \\
\text { COL) }\end{array}$ & Ionic gelation & $\begin{array}{l}\text { Particle size: } 200 \mathrm{~nm} \\
\text { Zeta potential: } 8,4 \mathrm{mV}\end{array}$ & $\begin{array}{l}\text {-Suppression of ovarian } \\
\text { cancer cell proliferation } \\
\text {-Significant accumulation } \\
\text { at the tumor site } \\
\text {-Active targeting ability }\end{array}$ & [27] \\
\hline $\begin{array}{l}\text { Dosetaksel / } \\
\text { gadolinium }\end{array}$ & Nano-emulsion & Folic acid & $\begin{array}{l}\text { Egg lecithin } \\
\text { DSPE-PEG }_{2000} \\
\text { DTPA-PE }^{\text {DTPA }}\end{array}$ & $\begin{array}{l}\text { High-shear } \\
\text { microfluidization }\end{array}$ & $\begin{array}{l}\text { Particle size: } 130-140 \mathrm{~nm} \\
\text { Zeta potential: }-50 \mathrm{mV}\end{array}$ & $\begin{array}{c}\text {-Significantly improved } \\
\text { cytotoxicity } \\
\text {-Extended period of } \\
\text { accumulation at tumor site }\end{array}$ & [29] \\
\hline
\end{tabular}

SKOV3 cells, indicating a strong synergism. Optimal cytotoxicity was observed at a 2:1 ratio of cisplatin:paclitaxel. In in-vivo fluorescence optical imaging studies, fluorescent dye encapsulated telodendrimers accumulated mainly at the SKOV-3 tumor xenograft, 4 -fold higher than other organs; whereas free dye showed very weak tumor fluorescence.
The pharmacokinetic behaviour of the free drug cisplatin was enhanced with slower clearance rates and higher plasma half-life. Furthermore, in-vivo anti-tumor efficacy studies indicated that the average tumor volume decrease was significantly higher for animal group treated with two drugs loaded telodendrimer group similar to in-vitro studies [25]. 


\section{Active targeting}

One of the key parameters for anticancer nanocarries is targeting ligands in addition to size and surface properties [24]. In ovarian cancer, highly expressed cell-surface proteins include the folate receptor, EGF receptor (EGFR, HER2), luteinizing hormone receptor, claudins, mucins, and integrins [3].

Fan et al. developed a nanoparticle system targeting the folliclestimulating hormone receptor (FSHR) loaded with paclitaxel to prevent lymphatic metastasis of ovarian cancer. Targeted nanoparticles showed improved cellular uptake into FSHR positive cells, NuTu-19, while there was no difference for non-targeted nanoparticles between FSHR positive and negative cells. In a model of ovarian cancer with lymphatic metastasis in rats, the drug concentration in lymph nodes for the animal group treated with targeted nanoparticles was observed to increase over time and was significantly higher than the free drug and non-targeted nanoparticle group. Moreover, the size and weight of the lymph nodes were reduced and average survival time was longer for the targeted nanoparticle group [26].

Since many genes involved in the regulation of proliferation and angiogenesis have been mutated during cancer, gene silencing via RNA interferences (RNAi) mediated by short interfering RNA (siRNA) is a great therapeutic target for cancer therapy. Hypoxic inducible factor-1a (HIF-1a) is an overexpressed protein in ovarian cancer and associated with cancer progression. Based on this information Li et al. developed tumor-targeting siRNA/folic acid- poly(ethylene glycol)chitosan oligosaccharide lactate (FA-PEG-COL) nanoparticles for HIF-1a suppression and therefore inhibition of angiogenesis and tumor growth. In vitro gene silencing studies made via Western Blot and Real time PCR demonstrated that siRNA delivery by FA-PEGCOL nanoparticles significantly reduced both protein and mRNA levels of HIF-1a, leading to a strong suppression of cell proliferation in human ovarian cancer cells. When fluorescent dye loaded FA-PEGCOL nanoparticles iv administered to nude mice bearing OVK18\#2 human ovarian cancer cells, significant accumulation at the tumor site was seen at $3 \mathrm{~h}$ post injection with subsequent increase at the 12 and $24 \mathrm{~h}$ time while significant liver accumulation was observed with COL nanoparticles treated animal group, indicating the active targeting ability of FA-PEG-COL nanoparticles [27].

Because of its multi-functional properties nanotechnology allows co-delivery of targeting ligands, drugs and imaging agents, which enables therapeutic, diagnostic and real-time traceable drug delivery goals to be achieved at the same time. This approach is called nanotheranostic [28]. By taking advantage of this superior property of nanotechnology Ganta et al. developed a folate targeted gadolinium decorated theranostic nanoemulsion of docetaxel for overcoming efflux transporters which are one of the chemoresistance mechanisms of ovarian cancer and tracing drug distribution. According to cellular uptake studies theranostic nanoemulsion uptake into folate receptor positive SKOV3 ovarian cancer cell line was time dependent and higher than nontargeted nanoparticles. MTT studies demonstrated that $\mathrm{IC}_{50}$ value of chemoresistant SKOV3TR decreased 270-fold compared to free drug. Magnetic resonance imaging study made thanks to gadolinium showed that folate targeted theranostic nanoparticles accumulated over the period of 24 hour at tumor site [29].

\section{Intraperitoneal chemotherapy}

Intraperitoneal (i.p) chemotherapy in other words the infusion of chemotherapeutic agents directly into the peritoneum is a promising option for ovarian cancer therapy due to spread of the disease to the peritoneal cavity [7,30,31]. Although there are some common drawbacks about i.p administration such as complications related to i.p infusion, including abdominal pain, intolerance to a high level of drug, and discomfort related to the catheter implantation, i.p chemotherapy can be beneficial to maintain an effective local drug concentration for a prolonged period and maximize the locoregional effects on residual tumors [30]. Another problem about i.p chemotherapy is rapid clearance of small molecule drugs from peritoneal cavity and necessity of frequent dosing [30]. In order to increase the residence time of the chemotherapeutics in the peritoneal cavity controlled release drug carriers, such as microparticles, hydrogels and bioadhesive nanoparticels [31].

Sun et al. developed a system comprising of in-situ crosslinkable hydrogel depot containing paclitaxel nanocrystals (PNC). PNC with $258 \pm 28.1 \mathrm{~nm}$ particle size and $-5.51 \pm 0.42 \mathrm{mV}$ zeta potential was produced by anti-solvent and temperature induced crystallization method while hyaluronic acid gel was produced by crosslinking HAadipic acid dihydrazide (HA-ADH) and HA-aldehyde (HA-CHO) in situ. PNC were more cytotoxic than microparticulate PTX in SKOV3 cell culture due to cellular PTX retention. After single dose intraperitoneal administration in vivo studies demonstrated that PNC-gel was more toxic than microparticulate PTX gel and extended survival of tumor-bearing mice because of greater antitumor effect than microparticulate PTX gel and free drug [30] (Table 1).

\section{Conclusion}

The use of nano drug delivery systems for ovarian cancer therapy is gaining more and more importance day by day due to their excellent properties and promising results. There are lots of nano-sized drug delivery systems designed for diagnosis and therapy under preclinical and clinical development and will be marketed a lot more in the near future.

\section{Funding}

The author(s) received no financial support for the research, authorship, and/or publication of this article.

\section{References}

1. Balch C, Huang TH, Brown R, Nephew KP (2004) The epigenetics of ovarian cance drug resistance and resensitization. Am J Obstet Gynecol 191: 1552-1572. [Crossref]

2. Holmes D (2015) Ovarian cancer: beyond resistance. Nature 527: S217. [Crossref]

3. Engelberth SA, Hempel N, Bergkvist M (2014) Development of Nanoscale Approaches for Ovarian Cancer Therapeutics and Diagnostics. Crit Rev Oncog 19: 281-315. [Crossref]

4. Kigawa J (2013) New strategy for overcoming resistance to chemotherapy of ovarian cancer. Yonago Acta Med 56: 43-50. [Crossref]

5. Sato S, Itamochi H (2015) Ovarian Cancer and Drug Resistance. Curr Obstet Gynecol Rep 4: 18-25

6. Banerjee S, Kaye SB (2013) New strategies in the treatment of ovarian cancer: curren clinical perspectives and future potential. Clin Cancer Res 19: 961-968. [Crossref]

7. Della Pepa C, Tonini G, Pisano C, Di Napoli M, Cecere SC, et al. (2015) Ovarian cancer standard of care: are there real alternatives? Chin J Cancer 34: 17-27. [Crossref]

8. Kim PS, Djazayeri S, Zeineldin R (2011) Novel nanotechnology approaches to diagnosis and therapy of ovarian cancer. Gynecol Oncol 120: 393-403. [Crossref]

9. Ren F, Shen J, Shi H, Hornicek FJ, Kan Q, et al. (2016) Novel mechanisms and approaches to overcome multidrug resistance in the treatment of ovarian cancer. Biochim Biophys Acta 1866: 266-275. [Crossref]

10. Guarneri V, Piacentini F, Barbieri E, Conte PF (2010) Achievements and unmet needs in the management of advanced ovarian cancer. Gynecol Oncol 117: 152-158. [Crossref] 
11. Gidwani B, Vyas A (2015) The potentials of nanotechnology-based drug delivery system for treatment of ovarian cancer. Artif Cells Nanomed Biotechnol 43: 291-297. [Crossref]

12. Florea AM, Busselberg D (2011) Cisplatin as an anti-tumor drug: cellular mechanisms of activity, drug resistance and induced side effects. Cancers (Basel) 3: 1351-1371. [Crossref]

13. Holohan C, Van Schaeybroeck S, Longley DB, Johnston PG (2013) Cancer drug resistance: an evolving paradigm. Nat Rev Cancer 13: 714-726. [Crossref]

14. Hall MD, Okabe M, Shen DW, Liang XJ, Gottesman MM (2008) The role of cellular accumulation in determining sensitivity to platinum-based chemotherapy. Annu Rev Pharmacol Toxicol 48: 495-535. [Crossref]

15. Matei DE, Nephew KP (2010) Epigenetic therapies for chemoresensitization of epithelial ovarian cancer. Gynecol Oncol 116: 195-201. [Crossref]

16. Dong Y, Batra J, Anand K, Bapat S, Clements JA (2014) Transforming the Future of Treatment for Ovarian Cancer. Clin Exp Pharmacol.

17. Tomasina J, Lheureux S, Gauduchon P, Rault S, Malzert-Fréon A (2013) Nanocarriers for the targeted treatment of ovarian cancers. Biomaterials 34: 1073-1101. [Crossref]

18. Steichen SD, Caldorera-Moore M, Peppas NA (2013) A review of current nanoparticle and targeting moieties for the delivery of cancer therapeutics. Eur J Pharm Sci 48 : 416-427. [Crossref]

19. Sawant RR, Jhaveri AM, Koshkaryev A, Zhu L, Qureshi F, et al. (2014) Targeted transferrin-modified polymeric micelles: enhanced efficacy in vitro and in vivo in ovarian carcinoma. Mol Pharm 11: 375-381. [Crossref]

20. Baranello MP, Bauer L, Benoit DS (2014) Poly(styrene-alt-maleic anhydride)based diblock copolymer micelles exhibit versatile hydrophobic drug loading, drugdependent release, and internalization by multidrug resistant ovarian cancer cells. Biomacromolecules 15: 2629-2641. [Crossref]

21. Aslan B, Ozpolat B, Sood AK, Lopez-Berestein G (2013) Nanotechnology in cancer therapy. J Drug Target 21: 904-913. [Crossref]

22. Alexis F, Pridgen EM, Langer R, Farokhzad OC (2010) Nanoparticle technologies for cancer therapy. Handb Exp Pharmacol : 55-86. [Crossref]

23. Xin Y, Huang Q, Tang JQ, Hou XY, Zhang P, et al. (2016) Nanoscale drug delivery for targeted chemotherapy. Cancer Lett 379: 24-31. [Crossref]

24. Drbohlavova J, Chomoucka J, Adam V, Ryvolova M, Eckschlager T, et al. (2013) Nanocarriers for anticancer drugs--new trends in nanomedicine. Curr Drug Metab 14: 547-564. [Crossref]
25. Cai L, Xu G, Shi C, Guo D, Wang X, et al. (2015) Telodendrimer nanocarrier for codelivery of paclitaxel and cisplatin: A synergistic combination nanotherapy for ovarian cancer treatment. Biomaterials 37: 456-468. [Crossref]

26. 26. Fan L, Chen J, Zhang X, Liu Y, Xu C (2014) Follicle-stimulating hormone polypeptide modified nanoparticle drug delivery system in the treatment of lymphatic metastasis during ovarian carcinoma therapy. Gynecol Oncol 135: 125-132. [Crossref]

27. Li TS, Yawata T, Honke K (2014) Efficient siRNA delivery and tumor accumulation mediated by ionically cross-linked folic acid-poly(ethylene glycol)-chitosan oligosaccharide lactate nanoparticles: for the potential targeted ovarian cancer gene therapy. Eur J Pharm Sci 52: 48-61. [Crossref]

28. Estanqueiro M, Amaral MH, Conceicao J, Sousa Lobo JM (2015) Nanotechnological carriers for cancer chemotherapy: the state of the art. Colloids Surf B Biointerfaces 126: 631-648. [Crossref]

29. Ganta S, Singh A, Rawal Y, Cacaccio J, Patel NR, et al. (2016) Formulation development of a novel targeted theranostic nanoemulsion of docetaxel to overcome multidrug resistance in ovarian cancer. Drug Deliv 23: 968-980. [Crossref]

30. Sun B, Taha MS, Ramsey B, Torregrosa-Allen S, Elzey BD, et al. (2016) Intraperitoneal chemotherapy of ovarian cancer by hydrogel depot of paclitaxel nanocrystals. J Control Release 235: 91-98. [Crossref]

31. Deng Y, Yang F, Cocco E, Song E, Zhang J, et al. (2016) Improved i.p. drug delivery with bioadhesive nanoparticles. Proc Natl Acad Sci USA 113: 11453-11458. [Crossref]

32. Cho H, Lai TC, Kwon GS (2013) Poly(ethylene glycol)-block-poly(epsiloncaprolactone) micelles for combination drug delivery: evaluation of paclitaxel, cyclopamine and gossypol in intraperitoneal xenograft models of ovarian cancer. $J$ Control Release 166: 1-9. [Crossref]

33. Phan V, Walters J, Brownlow B, Elbayoumi T (2013) Enhanced cytotoxicity of optimized liposomal genistein via specific induction of apoptosis in breast, ovarian and prostate carcinomas. J Drug Target 21: 1001-1011. [Crossref]

34. Shaikh IM, Tan KB, Chaudhury A, et al. (2013) Liposome co-encapsulation of synergistic combination of irinotecan and doxorubicin for the treatment of intraperitoneally grown ovarian tumor xenograft. J Control Release. [Crossref]

35. Matthaiou EI, Barar J, Sandaltzopoulos R, Li C, Coukos G, et al. (2014) Shikoninloaded antibody-armed nanoparticles for targeted therapy of ovarian cancer. Int $J$ Nanomedicine 9: 1855-1870. [Crossref]

Copyright: (C2017 Hascicek C. This is an open-access article distributed under the terms of the Creative Commons Attribution License, which permits unrestricted use, distribution, and reproduction in any medium, provided the original author and source are credited. 